\title{
Simulation of VaR Based on Monte Carlo-Copula - GARCH Model Yangfan Ren ${ }^{1, a}$ \\ ${ }^{1}$ Department of Mathematics and Physics,University of Science and Technology Beijing 30 Xueyuan Road, Beijing, 100083, China \\ a ryf960902@icloud.com
}

Keywords: Monte Carlo simulation, Copula, GARCH, VaR, Security

\begin{abstract}
In this paper, Monte Carlo method is used to establish the model of China's CITIC Securities and Huatai Securities for three years, and to test the accuracy of the model. Considering the non-normality of the distribution of the return rate of China's securities market, a GARCH model which can describe the spike and tail feature of variance and response rate distribution is used. The Monte Carlo algorithm is also improved by combining Copula function to compare.
\end{abstract}

\section{Introduction}

With the deepening of economic globalization and internationalization of capital flows, the global financial market has shown a trend of vigorous development. But at the same time, the ever-changing financial market has brought economic, social and political risk factors Significantly increased, leading to various types of financial institutions are facing increasingly serious systemic and non-systemic risk.

Monte Carlo method is often used in the calculation of VaR in financial risk measurement, but the Monte Carlo method also has the disadvantage such as too slow convergence. In this paper, the Monte Carlo method is compared with the Monte Carlo method combined with Copula-GARCH by estimating the $\mathrm{VaR}$ of the portfolio respectively.

\section{Basic statistical analysis of data}

The sample is based on the original data of CITIC Securities and Huatai Securities's closing price. The sample period is May 7, 2012 to May 20, 2016. CITIC Securities has a total of 985 closing price data. Huatai Securities has a total of 977 Closing price data. The above data comes from the RESSET database. The modeling and analysis methods are completed using Eviews 6.0 and Matlab.

First, we use Eviews6.0 for data statistics and description.

\section{Data Yield Price Trends.}

$Z X$

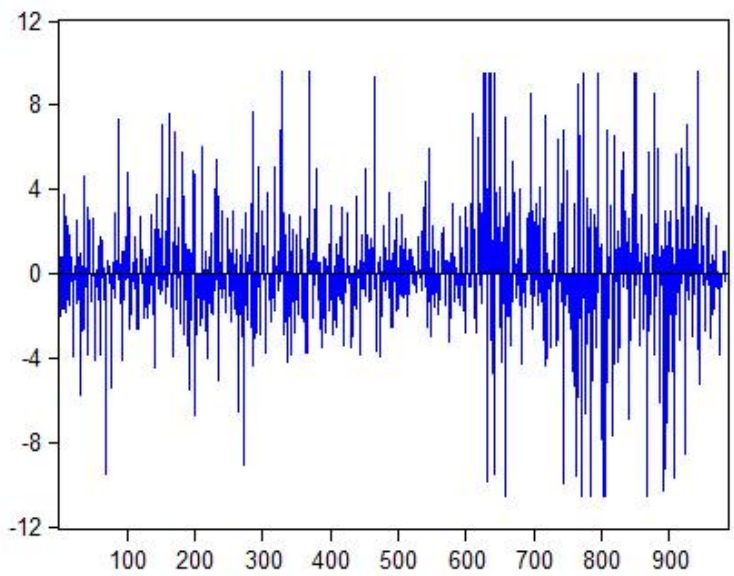

HT

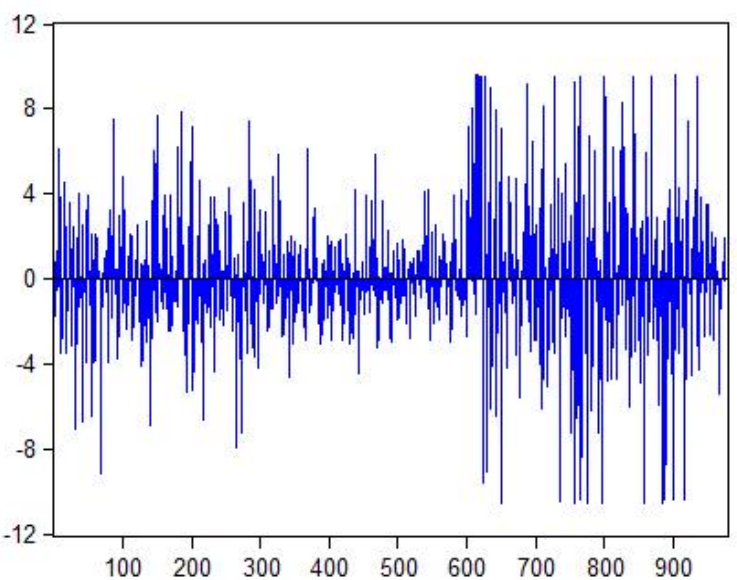

Fig. 1 Fluctuation of logistic yield series of CITIC Securities and Huatai Securities 
From Fig.1, the expected rate of return is zero, reflecting a certain degree of volatility and sequence fluctuations in the conditions of heterosexual signs which is not a random swimming process.

The positive test of the yield sequence. With further data analysis, we can obtain the mean, median, maximum, minimum, standard deviation, skewness, kurtosis, Jarque-Bera statistic and companion probability of CITIC Securities and Huatai Securites, as shown in Fig.2.

Fig.2 Data statistical analysis of CITIC Securities and Huatai Securities
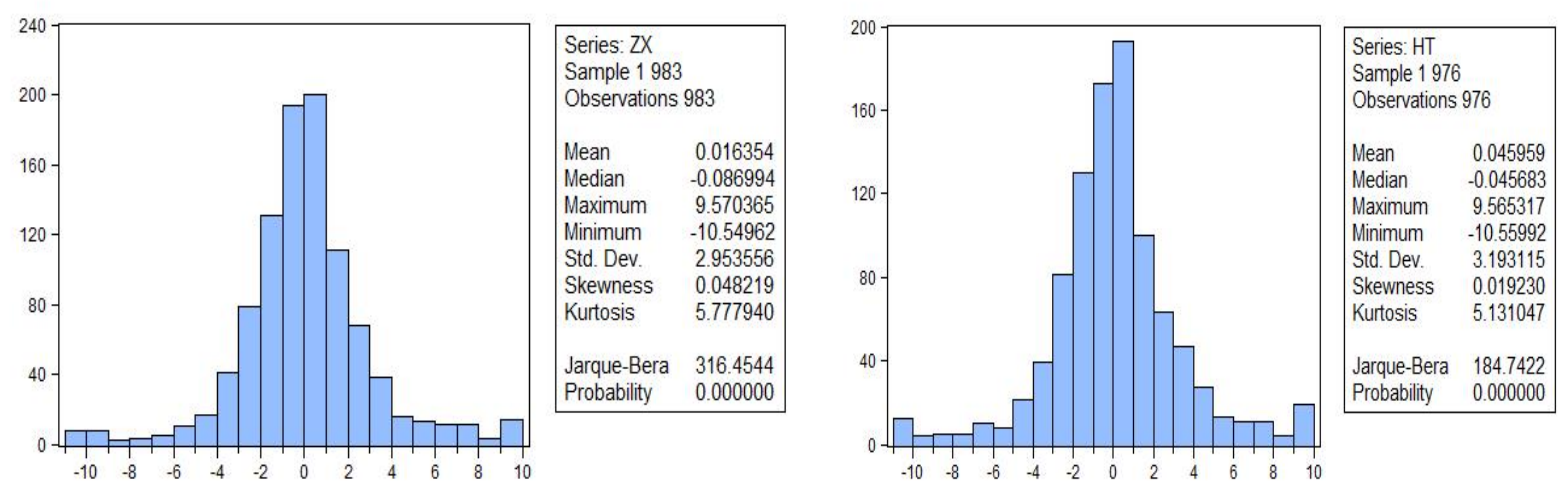

We assume that the random error $\mathrm{W}$ is subject to the normal distribution. The common normality test is the Jarque-Bera test, referred to as the JB test.

It can be seen from Fig. 2 that the JB statistic of the two stock returns are 316.4544 and 184.7422 . The skewness are 0.048219 and 0.019230 . The kurtosis are 5.777940 and 5.131047 . The Jarqne-Bera test has a p-value of 0.000000 , which rejects the original hypothesis at a confidence level of $99 \%$, which is not subject to a normal distribution.

Data stability test. In the actual research process, we usually use ADF (Augmented DF test) test. The following results were obtained with ADF test with Eviews, as shown in Fig.3.

Fig.3 Data stability test of CITIC Securities and Huatai Securities

Augmented Dickey-Fuller Unit Root Test on ZX

\section{Null Hypothesis: ZX has a unit root}

Exogenous: Constant

Lag Length: 0 (Automatic based on SIC, MAXLAG=21)

\begin{tabular}{lccc}
\hline \hline & t-Statistic & Prob. $^{*}$ \\
\hline \hline \multicolumn{2}{l}{ Augmented Dickey-Fuller test statistic } & -29.27053 & 0.0000 \\
\hline Test critical values: & 1\% level & -3.436789 & \\
& $5 \%$ level & -2.864272 & \\
& $10 \%$ level & -2.568277 & \\
\hline \hline
\end{tabular}

*MacKinnon (1996) one-sided p-values.

Augmented Dickey-Fuller Test Equation

Dependent Variable: D(ZX)

Method: Least Squares

Date: 06/14/16 Time: 19:39

Sample (adjusted): 2983

Included observations: 982 after adjustments

\begin{tabular}{lrlll}
\hline \hline \multicolumn{1}{c}{ Variable } & Coefficient & Std. Error & t-Statistic & Prob. \\
\hline \hline ZX(-1) & -0.932718 & 0.031865 & -29.27053 & 0.0000 \\
C & 0.017418 & 0.094112 & 0.185081 & 0.8532 \\
\hline \hline R-squared & 0.466453 & Mean dependent var & 0.003123 \\
Adjusted R-squared & 0.465909 & S.D. dependent var & 4.035404 \\
S.E. of regression & 2.949136 & Akaike info criterion & 5.002936 \\
Sum squared resid & 8523.456 & Schwarz criterion & 5.012895 \\
Log likelihood & -2454.442 & Hannan-Quinn criter. & 5.006724 \\
F-statistic & 856.7639 & Durbin-Watson stat & 2.000358 \\
Prob(F-statistic) & 0.000000 & & & \\
\hline \hline
\end{tabular}

\begin{tabular}{|c|c|c|c|}
\hline \multicolumn{4}{|c|}{ Augmented Dickey-Fuller Unit Root Test on HT } \\
\hline \multirow{3}{*}{\multicolumn{4}{|c|}{$\begin{array}{l}\text { Null Hypothesis: } H T \text { has a unit root } \\
\text { Exogenous: Constant } \\
\text { Lag Length: } 0 \text { (Automatic based on SIC, MAXLAG=21) }\end{array}$}} \\
\hline & & & \\
\hline & & & \\
\hline & & t-Statistic & Prob. * \\
\hline \multicolumn{2}{|c|}{ Augmented Dickey-Fuller test statistic } & -27.51046 & 0.0000 \\
\hline \multirow{3}{*}{ Test critical values: } & $1 \%$ level & -3.436837 & \\
\hline & $5 \%$ level & -2.864293 & \\
\hline & $10 \%$ level & -2.568288 & \\
\hline
\end{tabular}

*MacKinnon (1996) one-sided p-values.

Augmented Dickey-Fuller Test Equation

Dependent Variable: D(HT)

Method: Least Squares

Date: 06/15/16 Time: 08:34

Sample (adjusted): 2976

Included observations: 975 after adjustments

\begin{tabular}{lrlll}
\hline \hline \multicolumn{1}{c}{ Variable } & Coefficient & Std. Error & t-Statistic & Prob. \\
\hline \hline \multicolumn{1}{c}{ HT(-1) } & -0.875047 & 0.031808 & -27.51046 & 0.0000 \\
\multicolumn{1}{c}{ C } & 0.042300 & 0.101557 & 0.416518 & 0.6771 \\
\hline \hline R-squared & 0.437516 & Mean dependent var & 0.003773 \\
Adjusted R-squared & 0.436937 & S.D. dependent var & 4.225660 \\
S.E. of regression & 3.170829 & Akaike info criterion & 5.147912 \\
Sum squared resid & 9782.695 & Schwarz criterion & 5.157928 \\
Log likelihood & -2507.607 & Hannan-Quinn criter. & 5.151724 \\
F-statistic & 756.8255 & Durbin-Watson stat & 1.994720 \\
Prob(F-statistic) & 0.000000 & & & \\
\hline
\end{tabular}


As can be seen in Fig.3, the ADF values of the yield series are $-29.27053,-27.51046$, less than 1\%, $5 \%$ and $10 \%$ confidence intervals. The probability is almost zero, that is, there is no unit root, which indicates that the sample index yield sequence is very smooth.

Data autocorrelation test. If there is a correlation between the time series data among the residuals, this will make the variable inactive feedback. The LQ method is used to test autocorrelation and partial correlation.

\begin{tabular}{|c|c|c|c|c|c|c|}
\hline \multicolumn{7}{|c|}{ Correlogram of ZX } \\
\hline \multicolumn{7}{|c|}{$\begin{array}{l}\text { Date: } 06 / 14 / 16 \text { Time: } 19: 40 \\
\text { Sample: } 1983 \\
\text { Included observations: } 983\end{array}$} \\
\hline Autocorrelation & Partial Correlation & & $A C$ & PAC & Q-Stat & Prob \\
\hline 中 & 中 & 1 & 0.067 & 0.067 & 4.4624 & 0.035 \\
\hline$\sqrt{1}$ & $\sqrt{1}$ & 2 & 0.005 & 0.000 & 4.4842 & 0.106 \\
\hline 川1 & 川 & & -0.020 & -0.021 & 4.8878 & 0.180 \\
\hline 1) & 1) & 4 & 0.032 & 0.035 & 5.8887 & 0.208 \\
\hline 中 & 中 & 5 & 0.031 & 0.027 & 6.8357 & 0.233 \\
\hline d & d & 6 & -0.044 & -0.049 & 8.7784 & 0.186 \\
\hline 中 & 中 & 7 & 0.045 & 0.053 & 10.825 & 0.146 \\
\hline 卢 & 15 & 8 & 0.069 & 0.064 & 15.596 & 0.049 \\
\hline 㠼 & 中 & 9 & 0.098 & 0.086 & 25.164 & 0.003 \\
\hline di & d & 10 & -0.030 & -0.039 & 26.035 & 0.004 \\
\hline 11 & 中 & 11 & 0.006 & 0.013 & 26.070 & 0.006 \\
\hline 小 1 & 小 & 12 & 0.006 & 0.000 & 26.104 & 0.010 \\
\hline 中 & 1) & 13 & 0.046 & 0.040 & 28.243 & 0.008 \\
\hline d & d & 14 & -0.041 & -0.047 & 29.885 & 0.008 \\
\hline M & 小 & 15 & -0.013 & -0.003 & 30.058 & 0.012 \\
\hline 中 & 中 & 16 & 0.050 & 0.038 & 32.606 & 0.008 \\
\hline 中 & 中 & 17 & 0.043 & 0.026 & 34.419 & 0.007 \\
\hline 中 & 中 & 18 & 0.060 & 0.050 & 37.994 & 0.004 \\
\hline 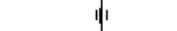 & 小 & 19 & -0.009 & -0.003 & 38.077 & 0.006 \\
\hline 中 & 中 & 20 & 0.030 & 0.020 & 38.975 & 0.007 \\
\hline 中 & 中 & 21 & 0.061 & 0.056 & 42.701 & 0.003 \\
\hline 小 & 11 & 22 & 0.002 & -0.009 & 42.705 & 0.005 \\
\hline ¿ & 4 & 23 & -0.087 & -0.081 & 50.252 & 0.001 \\
\hline 中 & 中 & 24 & 0.028 & 0.037 & 51.064 & 0.001 \\
\hline 中 & 中 & 25 & 0.071 & 0.049 & 56.175 & 0.000 \\
\hline 11 & 1 & 26 & -0.018 & -0.043 & 56.495 & 0.000 \\
\hline 11 & 川 & 27 & -0.024 & -0.018 & 57.074 & 0.001 \\
\hline 中 & 中 & 28 & 0.056 & 0.065 & 60.287 & 0.000 \\
\hline |' & 1 & 29 & 0.004 & -0.034 & 60.301 & 0.001 \\
\hline 4 & 4 & 30 & -0.053 & -0.056 & 63.198 & 0.000 \\
\hline q & q & 31 & -0.080 & -0.055 & 69.683 & 0.000 \\
\hline q & 1 & 32 & -0.058 & -0.045 & 73.066 & 0.000 \\
\hline 小 & 川 & 33 & 0.002 & -0.018 & 73.068 & 0.000 \\
\hline 11 & 11 & 34 & -0.006 & -0.010 & 73.102 & 0.000 \\
\hline 4 & |' & 35 & -0.014 & -0.004 & 73.316 & 0.000 \\
\hline q & 1 & 36 & -0.030 & -0.030 & 74.219 & 0.000 \\
\hline
\end{tabular}

\begin{tabular}{|c|c|c|c|c|c|c|}
\hline \multicolumn{7}{|c|}{ Correlogram of $\mathrm{HT}$} \\
\hline \multicolumn{7}{|c|}{$\begin{array}{l}\text { Date: } 06 / 15 / 16 \text { Time: } 08: 35 \\
\text { Sample: } 1976 \\
\text { Included observations: } 976\end{array}$} \\
\hline Autocorrelation & Partial Correlation & & $\mathrm{AC}$ & PAC & Q-Stat & Prob \\
\hline 旧 & 师 & 1 & 0.125 & 0.125 & 15.275 & 0.000 \\
\hline 11 & 11 & & -0.005 & -0.021 & 15.298 & 0.000 \\
\hline$\|$ & $\|$ & & -0.016 & -0.013 & 15.548 & 0.001 \\
\hline 中 & 中 & 4 & 0.041 & 0.046 & 17.227 & 0.002 \\
\hline ו & 中 & & 0.027 & 0.016 & 17.959 & 0.003 \\
\hline d & d & & -0.040 & -0.046 & 19.528 & 0.003 \\
\hline מ & i] & 7 & 0.048 & 0.062 & 21.758 & 0.003 \\
\hline 中 & 小 & 8 & 0.021 & 0.005 & 22.173 & 0.005 \\
\hline 中 & 中 & 9 & 0.019 & 0.014 & 22.538 & 0.007 \\
\hline d & d & 10 & -0.049 & -0.049 & 24.925 & 0.005 \\
\hline in & 少 & 11 & 0.012 & 0.024 & 25.071 & 0.009 \\
\hline 中 & 1) & 12 & 0.049 & 0.039 & 27.461 & 0.007 \\
\hline ط & ק & 13 & 0.108 & 0.100 & 38.925 & 0.000 \\
\hline 中 & 1 & 14 & -0.018 & -0.043 & 39.244 & 0.000 \\
\hline$\|$ & 小 & 15 & -0.017 & -0.005 & 39.545 & 0.001 \\
\hline 小 & N & 16 & -0.006 & -0.012 & 39.585 & 0.001 \\
\hline$\|$ & $\|$ & 17 & -0.010 & -0.013 & 39.683 & 0.001 \\
\hline ip & ip & 18 & 0.028 & 0.031 & 40.472 & 0.002 \\
\hline 小 & 小 & 19 & -0.005 & -0.003 & 40.494 & 0.003 \\
\hline 中 & 中 & 20 & 0.063 & 0.049 & 44.473 & 0.001 \\
\hline 中 & ip & 21 & 0.050 & 0.040 & 46.989 & 0.001 \\
\hline 川 & d & 22 & -0.015 & -0.028 & 47.226 & 0.001 \\
\hline d & d & 23 & -0.045 & -0.030 & 49.289 & 0.001 \\
\hline 小 & |' & 24 & -0.003 & 0.001 & 49.296 & 0.002 \\
\hline 中 & 1) & 25 & 0.049 & 0.032 & 51.715 & 0.001 \\
\hline 少 & 小 & 26 & 0.010 & -0.005 & 51.819 & 0.002 \\
\hline |' & |' & 27 & -0.005 & 0.003 & 51.844 & 0.003 \\
\hline 中 & 中 & 28 & 0.063 & 0.068 & 55.842 & 0.001 \\
\hline$\|$ & di & 29 & -0.013 & -0.038 & 56.010 & 0.002 \\
\hline d & d & 30 & -0.039 & -0.028 & 57.573 & 0.002 \\
\hline qu & ' & 31 & -0.074 & -0.067 & 63.141 & 0.001 \\
\hline d & d & 32 & -0.037 & -0.033 & 64.490 & 0.001 \\
\hline 小 & $\|$ & 33 & 0.003 & -0.009 & 64.502 & 0.001 \\
\hline 11 & $\|$ & 34 & -0.021 & -0.017 & 64.946 & 0.001 \\
\hline |' & 少 & 35 & 0.001 & 0.019 & 64.948 & 0.002 \\
\hline d & di & 36 & -0.036 & -0.029 & 66.289 & 0.002 \\
\hline
\end{tabular}

Fig.4 Data autocorrelation test of CITIC Securities and Huatai Securities

From the Fig.4, we can see that the data are mostly in the confidence interval. Q statistic is not significant, until the value of the lag 36 order is less than the critical value of the significance level, indicating that the yield sequence exists autocorrelation and ARCH effect .

\section{VaR calculation based on Monte Carlo method}

Using the above selected data, the VaR value of the next trading day (ie May 23, 2016) is calculated by Monte Carlo method. The holding period is 1 day. Assuming that the confidence level is 95\%, we use the geometric Brownian motion as a stochastic model for the change of the price of CITIC securities. The holding period of the day is divided into 20 equal periods. Each mean and standard deviation of the time period are $\frac{\mu}{20}, \frac{\sigma}{\sqrt{20}}$.

The followings are specific steps of calculation of CITIC Securities VaR on May 23, 2020 using general Monte Carlo simulation method.

Estimate the mean and standard deviation. We estimate the $\mu$ and the standard deviation $\sigma$ between CITIC Securities and Huatai Securities on May 20, 2012 to May 20, 2016. Then we calculate the mean return of CITIC securities in each period of time $\frac{\mu}{20}$ and the standard deviation $\frac{\sigma}{\sqrt{20}}$.

Generate random numbers. Generate 20 random numbers that obey the standard normal distribution $\varepsilon_{1}, \varepsilon_{2}, \cdots, \varepsilon_{20}$. 
Simulate a possible path to a change in the price of a security. The gain of $\mathrm{t}+1$ is obtained by substituting $S_{t}$ (yield on May 20, 2016), $\frac{\mu}{20}, \frac{\sigma}{\sqrt{20}}$ and $\varepsilon_{i}$ into the formula and we get

$$
S_{t+1}=S_{t}+S_{t}\left(\frac{\mu}{20} \Delta t+\frac{\sigma}{\sqrt{20}} \varepsilon_{1} \sqrt{\Delta t}\right)
$$

And so on we have

$$
S_{t+2}=S_{t+1}+S_{t+1}\left(\frac{\mu}{20} \Delta t+\frac{\sigma}{\sqrt{20}} \varepsilon_{2} \sqrt{\Delta t}\right)
$$

$$
S_{t+20}=S_{t+19}+S_{t+19}\left(\frac{\mu}{20} \Delta t+\frac{\sigma}{\sqrt{20}} \varepsilon_{20} \sqrt{\Delta t}\right)=S_{T}
$$

$S_{t+1}, S_{t+2}, \cdots, S_{t+20}$ is a possible path for the change of the two kinds of securities, and $S_{T}$ is the possible rate of return on May 23, 2016.

Simulation of the May 20, 2016 two kinds of securities 100 possible rate of return. Repeat the step 2 and 3 for 100 times so that we get 100 possible yield of the two kinds of securities as $S_{T}^{1}, S_{T}^{2}, \ldots \ldots, S_{T}^{100}$. We array the time $\mathrm{T}$ in ascending order. Given the confidence level (1- $\left.\alpha\right)$, we find the VaR of the confidence level (1- $\alpha)$ and the quantile $S_{T}^{*}$ (that is, the k $\alpha$-th simulation price) of $100 \alpha \%$.

$$
\mathrm{VaR}=S_{t}-S_{T}^{*}
$$

The total investment rate of the portfolio $R_{P}=\sum_{n=1}^{2} w_{n} S_{n t+1}, w_{1}=w_{2}=\frac{1}{2}$. Given the confidence level, VaR can be obtained. Using Matlab to program the above steps, you can calculate the VaR of the portfolio for the next trading day (May 23, 2016) as shown in Table 1:

Table 1 Calculation results of VaR based on MC method

\begin{tabular}{|c|c|c|}
\hline Significance level & $95 \%$ & $99 \%$ \\
\hline VaR & 2.5724 & 1.8793 \\
\hline
\end{tabular}

Test the VaR model with the failure frequency test method given by Kupiec. In the failure frequency test, it is assumed that the confidence degree of calculating $\mathrm{VaR}$ is c, the actual inspection number of days is $\mathrm{T}$ and the number of failed days is $\mathrm{N}$, the failure frequency is: $\mathrm{p}=\mathrm{N} / \mathrm{T}$.

On the basis of the previous part, we use Matlab to calculate 100 times to get 100 days' daily trading VaR using 95\% and 99\% confidence levels respectively. The test results are shown in Table 2.

Table 2 VaR model test results based on MC method

\begin{tabular}{|c|c|c|}
\hline Significance level & $95 \%$ & $99 \%$ \\
\hline Non-refusal interval & $37<\mathrm{N}<65$ & $4<\mathrm{N}<17$ \\
\hline Actual days & 59 & 21 \\
\hline
\end{tabular}

The results in Table 2 show that the model is acceptable at the 95\% confidence level. But there are 21 failed days at the 99\% confidence level that exceeds the maximum value of the non-rejected area, indicating that the model is underestimated Actual loss value.

\section{VaR calculation based on copula-GARCH-MC method}

Parameter estimation of the GARCH model. The general expression of the GARCH $(1,1)$ model can be written as:

$$
\begin{aligned}
& r_{t}=x \beta^{\prime}+\varepsilon_{t} \\
& h_{t}^{2}=\omega+\alpha \varepsilon_{t-1}^{2}+\beta h_{t-1}^{2}
\end{aligned}
$$




$$
\varepsilon_{t}=v_{t} h_{t}
$$

$r_{t}$ is the conditional mean and $h_{t}^{2}$ is the conditional variance. A is the return coefficient, $\beta$ is the hysteresis coefficient, and the size of the parameters $\alpha$ and $\beta$ determines the shape of the volatility sequence. $v_{t}$ is an independently distributed random variable, $h_{t}$ and $v_{t}$ are independent of each other. It is often assumed that $v_{t}$ is a standard normal distribution.

The parameters of the GARCH $(1,1)$ model are estimated from the CITIC Securities and Huatai Securities yield data for the entire time period from May 7, 2012 to May 20, 2016. The parameters of the GARCH $(1,1)$ model are as Fig.5:

Dependent Variable: $Z X$

Method: ML - ARCH (Marquardt) - Normal distribution

Date: 06/14/16 Time: 20:56

Sample: 1983

Included observations: 983

Convergence achieved after 11 iterations

Presample variance: backcast (parameter $=0.7$ )

$\mathrm{GARCH}=\mathrm{C}(2)+\mathrm{C}(3)^{\star} \mathrm{RESID}(-1)^{\wedge} 2+\mathrm{C}(4)^{\star} \mathrm{GARCH}(-1)$

\begin{tabular}{ccccc}
\hline \hline Variable & Coefficient & Std. Error & z-Statistic & Prob. \\
\hline \hline C & 0.000189 & 0.000862 & 0.219917 & 0.8259 \\
\hline \hline \multicolumn{5}{c}{ Variance Equation } \\
RESID(-1) 2 & $1.38 \mathrm{E}-05$ & $3.36 \mathrm{E}-06$ & 4.114497 & 0.0000 \\
GARCH(-1) & 0.057058 & 0.008968 & 6.362310 & 0.0000 \\
\hline \hline R-squared & 0.927430 & 0.009853 & 94.12914 & 0.0000 \\
Adjusted R-squared & -0.000001 & Mean dependent var & 0.000164 \\
S.E. of regression & -0.000001 & S.D. dependent var & 0.029536 \\
Sum squared resid & 0.029536 & Akaike info criterion & -4.359772 \\
Log likelihood & 0.856648 & Schwarz criterion & -4.339871 \\
Durbin-Watson stat & 2146.828 & Hannan-Quinn criter. & -4.352202 \\
\hline \hline
\end{tabular}

\begin{tabular}{|c|c|c|c|c|}
\hline \multicolumn{5}{|c|}{$\begin{array}{l}\text { Dependent Variable: HT } \\
\text { Method: ML - ARCH (Marquardt) - Normal distribution } \\
\text { Date: } 06 / 15 / 16 \text { Time: } 08: 40 \\
\text { Sample: } 1976 \\
\text { Included observations: } 976 \\
\text { Convergence achieved after } 8 \text { iterations } \\
\text { Presample variance: backcast (parameter }=0.7) \\
\text { GARCH }=\mathrm{C}(2)+\mathrm{C}(3)^{\star} \operatorname{RESID}(-1)^{\wedge} 2+\mathrm{C}(4)^{\star} \mathrm{GARCH}(-1)\end{array}$} \\
\hline Variable & Coefficient & Std. Error & z-Statistic & Prob. \\
\hline $\mathrm{C}$ & 0.000320 & 0.000836 & 0.383351 & 0.7015 \\
\hline \multicolumn{5}{|c|}{ Variance Equation } \\
\hline $\begin{array}{c}\mathrm{C} \\
\operatorname{RESID}(-1)^{\wedge} 2 \\
\operatorname{GARCH}(-1)\end{array}$ & $\begin{array}{l}6.59 E-06 \\
0.064552 \\
0.930408\end{array}$ & $\begin{array}{l}2.70 \text { E-06 } \\
0.010313 \\
0.009639\end{array}$ & $\begin{array}{l}2.437757 \\
6.259037 \\
96.52697\end{array}$ & $\begin{array}{l}0.0148 \\
0.0000 \\
0.0000\end{array}$ \\
\hline $\begin{array}{l}\text { R-squared } \\
\text { Adjusted R-squared } \\
\text { S.E. of regression } \\
\text { Sum squared resid } \\
\text { Log likelihood } \\
\text { Durbin-Watson stat }\end{array}$ & $\begin{array}{r}-0.000019 \\
-0.000019 \\
0.031931 \\
0.994127 \\
2093.019 \\
1.749469\end{array}$ & \multicolumn{2}{|c|}{$\begin{array}{l}\text { Mean dependent var } \\
\text { S.D. dependent var } \\
\text { Akaike info criterion } \\
\text { Schwarz criterion } \\
\text { Hannan-Quinn criter. }\end{array}$} & $\begin{array}{r}0.000460 \\
0.031931 \\
-4.280776 \\
-4.260762 \\
-4.273160\end{array}$ \\
\hline
\end{tabular}

Fig.5 GARCH $(1,1)$ model parameters of CITIC Securities and Huatai Securities

The result of Fig.5 is expressed by the equations:

$$
\begin{aligned}
& r_{t}=0.000189+\varepsilon_{t} \\
& h_{t}^{2}=1.38 * 10^{-5}+0.057058 \varepsilon_{t-1}^{2}+0.927430 h_{t-1}^{2} \\
& r_{t}=0.000320+\varepsilon_{t} \\
& h_{t}^{2}=6.59 * 10^{-6}+0.064552 \varepsilon_{t-1}^{2}+0.930408 h_{t-1}^{2}
\end{aligned}
$$

Calculation and testing of VaR. The Monte Carlo simulation is used to simulate the future earnings of the two stocks selected in this paper. The specific methods are as follows.

The GARCH $(1,1)-t$ model is used to fit each asset yield sequence. $\xi_{t}$ obey the distribution of $t_{v}(0,1)$, and then converted into $t_{v}\left(\xi_{t}\right) \sim \mathrm{U}(0,1)$. The residual sequence $t_{v}\left(\xi_{t}\right) \sim \mathrm{U}(0,1)$ is obtained.

Estimation of the parameter $\boldsymbol{\theta}$ of Copula function with maximal likelihood. Monte Carlo simulations are used to generate random numbers $\left(u_{1}, u_{2}\right)$ with t-Copula function distributions. With the inverse probability integral we get $\left(\xi_{1}, \xi_{2}\right)=\left(t_{1}^{-1}\left(u_{1}\right), t_{2}^{-1}\left(u_{2}\right)\right.$. Replace $\left(\xi_{1}, \xi_{2}\right)$ into the volatility equation to obtain the next model of the analog yield.

Repeat the simulation 100 times. Get 100 groups of distribution $\mathrm{F}\left(\xi_{1}, \xi_{2}\right)$, the entire portfolio simulation yield $R_{P}=\sum_{n=1}^{2} w_{n} S_{n t+1}, w_{1}=w_{2}=\frac{1}{2}$. Given the confidence level, VaR can be obtained.

Calculate the VaR of the portfolio for the next trading day (May 23, 2016) as shown in Table 3:

Table 3 VaR calculation results based on copula-GARCH $(1,1)$ method

\begin{tabular}{|c|c|c|}
\hline Significance level & $95 \%$ & $99 \%$ \\
\hline VaR & 2.5029 & 1.9981 \\
\hline
\end{tabular}


Ibid, using the failure frequency test given by the upiec to verify the accuracy of the VaR model.

Table 4 Test results of VaR model based on copula-GARCH $(1,1)$ method

\begin{tabular}{|c|c|c|}
\hline Significance level & $95 \%$ & $99 \%$ \\
\hline Non-refusal interval & $37<\mathrm{N}<65$ & $4<\mathrm{N}<17$ \\
\hline Actual days & 52 & 16 \\
\hline
\end{tabular}

The results in Table 4 show that at both $95 \%$ and $99 \%$ of the confidence level did not exceed the non-rejected area, indicating that the combination of the Copula-GARCH model with the Monte Carlo method is more accurate than merely using the Monte Carlo method.

\section{Conclusions}

Through the above analysis, we can find that CITIC Securities and Huatai Securities have high peak tail non-normality, fluctuation clustering and ARCH effect. Through the empirical comparison of MC simulation method and Copula-GARCH-MC simulation method, we find that the latter is more effective and more conducive to investors to determine the risk of investment.

Copula-GARCH is a good multivariable financial time series model. In the empirical application research, different models can be used to construct some new Copula functions such as EGARCH, TGARCH and GARCH-M to describe the marginal distribution.

\section{References}

[1] Zhongji Xu, in: Monte Carlo method, edited by Shanghai Science and Technology Publications (1985), in press.

[2] Chunfeng Wang, in: Financial Market Risk Management, edited by Tianjin University Publications (2001), in press.

[3] Nengfu Zhang, Shiling Zhao: Research on Science and Technology Management, 2010,10: 223-226.

[4] Shijuan Yang, Weixue lu: Journal of Huangshan University, 2015,17 (3): 1-4.

[5] Bo Yu, Xizhen Chen, Dong Hua: Science Technology and Engineering, 2008,8 (5): 1243-1246.

[6] Lei Chen, Ruoen Chen, Jinbao Zhang: Systems Engineering, 2006,24 (7): 57-61.

[7] Kaiwei Wu, Juan Chen: Journal of Jimei University, 2009,12 (2): 44-47. 